\title{
Examining the Drivers of Stock Prices of Private Sector Banks in India
}

\author{
Rajveer S. Rawlin* Savitha Rani Ramachandran Keerthana K R \\ M S Ramaiah Institute of Management, M S Ramaiah Nagar, MSRIT Post, Bengaluru 560054, India \\ * E-mail of the corresponding author: rajveer@msrim.org
}

\begin{abstract}
Indian private sector banking stocks have been rebounding from a massive selloff. Private sector banks which have traditionally maintained their asset quality and profitability when compared to their public-sector counterparts, have recently seen their asset quality erode. Given that private sector banks play an influential role in the Indian economy, it would be helpful to understand the key drivers of private bank stock prices. This paper studied the influence of some key micro and macro determinants on the stock prices of all listed private sector banks in India over the 12 years from 2008-2019. Panel regression models were fit to study the relationship between the variables. Liquidity, profitability, growth, inflation and exchange rate indicators proved to be important influencers of the stock prices of private sector banks in India. The study provides evidence for the Fisher effect suggesting that private bank stocks can provide good inflation adjusted returns over time. Stakeholders of these banks can focus on these determinants which will contribute to shareholder value over time.
\end{abstract}

Keywords: Indian Private Banks, Stock Market capitalization, Liquidity, Exchange rates, GDP, Panel regression DOI: $10.7176 / \mathrm{EJBM} / 13-11-04$

Publication date:June $30^{\text {th }} 2021$

\section{Introduction}

Indian banking stocks have been bouncing back after a major rout following the COVID 19 crisis. This is on the back of severely deteriorating asset quality in the Indian banking landscape over the last decade. The deteriorating asset quality while more pronounced in public sector banks has also spread to private sector banks.

The Indian banking system includes public sector banks, private sector banks, foreign banks, small finance banks, payment banks, and regional rural banks. While public sector banks are majority owned by the government and cater to vast segments of the society that includes marginalized and priority segments, private sector banks are more focused in targeting fewer segments, focusing more on asset quality and profitability.

Given that banks in the private sector in India play an influential role in propelling the economy forward it would be useful to ascertain the drivers of stock prices of banks in this sector. This in turn can throw light on key performance measures such as shareholder value creation, market value added and valuation ratios.

Globally bank stock prices are influenced by various factors. These include micro determinants such as profitability (Kazi, 2009), asset quality (D'Apolito and Pacelli, 2017), technical efficiencies (Pasiouras et al., 2008), management quality (Rjoub, Civcir, \& Resatoglu 2017), and macro variables such as interest rates (English et al., 2018) and exchange rates (Eita, 2012).

In the present study, we examine the influence of some key micro and macro determinants on the stock market capitalization of India's listed private sector banks. The micro variables chosen include measures of profitability, income measures, productivity measures, liquidity measures, cost efficiency measures, and measures of capital adequacy, asset quality, and lending efficiency. The macro variables chosen include measures of growth, inflation, and exchange rates. The study additionally looks for evidence for established market theories such as the fisher effect (Fisher, 1930).

\section{Literature Review}

There are many key drivers of the stock price performance of banks which have been identified in some earlier studies. These include micro and macro-economic variables.

\subsection{Micro variables}

The impact of income measures on stock performance have been examined in studies covering six banks listed on the Singapore exchange (Chu \& Lim, 1998) and a sample of European banks (Beccalli, Casu \& Girardone, 2006). They observed that changes in cost and operating efficiency influenced stock price performance. Beccalli, Casu \& Girardone, 2006 found that the share price performances of cost-efficient banks were much better than banks possessing cost inefficiencies. Chu \& Lim, 1998 found that share price performance was impacted more by changes in profitability when compared to changes in cost efficiency.

Studies looking at the effect of Earnings and earnings releases on stock price performance of banks has been carried out on leasing and insurance companies in Bangladesh (Uddin 2009), 14 Jordanian Banks (Al-Shubiri, F N (2010), Malaysian bank (Seetharaman \& Raj 2011), Indian Commercial Banking sector (Srinivasan, 2012), 
Jordanian Banks listed in Amman Stock exchange (Almumani, 2014), Listed banks in Nigeria (Lucky, Akani \& Chukwuemeka, 2015) and sample of Turkish banks (Rjoub, Civcir, \& Resatoglu 2017). They found that earnings, dividend yield, Return on Assets (ROA), Earnings per share (EPS) and Price-Earnings (P/E) ratio had a strong impact of the stock prices. Kazi, (2009) found that micro factors such as corporate profitability and dividend impacted Australian stock market returns.

On the other hand, Ali and Chowdhury, 2010 found no major impact of dividend declaration on the share prices of a sample of listed Private Commercial Banks (PCBs) in Bangladesh. Menaje, (2012) studied the impact of micro variables such as the EPS, cash flow per share, dividend per share on share prices of ten listed banks on the Philippine stock exchange, through a multiple regression framework. This study also found that these variables did not influence bank share prices. Naveed \& Ramzan (2013) investigated the micro variables of dividend yield, ROA, asset growth of fifteen banks listed on Karachi Stock Exchange and found that these variables had an insignificant relationship with share prices. Ghauri (2014) whose study focused on 15 listed banks on the Karachi stock exchange found that key micro variables such as dividend yield and ROA did not have a significant relationship with bank share prices.

Lending measures and their impact on stock prices has not been studied in most studies related to micro variables. Investigating 14 Jordanians Commercial Banks, Al-Shubiri (2010) found that lending interest rate had a negative relationship with stock prices. Lucky, Akani \& Chukwuemeka, (2015) examined the impact of lending rate on stock prices of listed commercial banks in Nigeria and found the relationship to be insignificant.

Productivity is another key micro measure which reflects the efficacy of the bank's operations. Pasiouras et al., (2008) looked at the impact of technical and scale efficiency on the stock price performance of Greek banks from 2001 to 2005. It was observed that variations in technical efficiency positively impacted stock price performance while variations in scale efficiency did not affect stock price returns. Further, a study covering a sample of Turkish banks (Rjoub, Civcir, \& Resatoglu 2017) found that management quality significantly influenced Turkish bank stock prices.

The influence of capital adequacy, asset quality, and liquidity measures on bank stock prices has been examined by D'Apolito \& Pacelli (2017) in their study covering the impact of key balance sheet ratios on the stock prices of European banks. It was found that European banks' stock prices were influenced positively by asset quality, liquidity, and capital ratios of banks. Investigations into 15 listed commercial banks in Nigeria by Lucky, Akani \& Chukwuemeka, (2015) regarding bank's capital to total assets revealed a positive and significant relationship with stock prices. A study of Turkish banks by Rjoub, Civcir, \& Resatoglu (2017) also concluded that the micro variable of asset quality positively impacted the Turkish bank stock prices.

\subsection{Macro variables}

Most studies focusing on macro variables look at variables such as interest rates, exchange rates, money supply, economic activity etc. The conclusions from various studies reveal a mixed result with many studies showing a significant relationship between macro variables and bank stock prices while there are also a good number of studies indicating a negative impact of macro variables on bank stock prices.

According to the Fisher effect stock prices and inflation move in the same direction. Thus as inflation rises, stock prices will also rise and hence act as a hedge against inflation (Fisher, 1930). The proxy hypothesis on the other hand suggests that there may be a negative relationship between stock prices and inflation driven by changes in real economic activity. If economic activity were to rise but money supply didn't, then inflation would remain subdued and would not accompany rising stock prices (Fama, 1981).

Eita, (2012) looked at the influence of key macro-economic factors on stock prices in Namibia. This was done through econometric analysis utilizing the VECM approach. It was observed that stock prices in Namibia were impacted by interest rates, economic activity, inflation, the money supply, and exchange rates. Increasing economic growth and money supply impacted stock price performance positively. Increases in inflation and interest rates resulted in lower stock price performance. Kazi, (2009) found that macro factors such as the level of interest rates, industrial activity, and performance of other global markets impacted Australian stock market returns. Rjoub, Civcir, \& Resatoglu, (2017) looked at the impact of key macro variables on the share prices of a sample of Turkish banks. The macroeconomic variables money supply and interest rates significantly impacted bank stock prices in Turkey. A similar result was observed by Lucky, Akani \& Chukwuemeka, (2015) in their study covering 15 listed commercial banks in Nigeria.

Ali et al., (2018) used panel regression to study the drivers of bank stock prices in Pakistan in the period between January 2005 and December 2013. It was found that share prices rose during booms in economic activity and declined during periods of currency depreciation and interest rate increases. English et al., (2018) analyzed the impact of interest rate shocks induced by Federal Reserve rate announcements on bank equity valuations in the US. They found that bank stock prices declined when the yield curve steepened more than expected. This resulted in banks having to choose more expensive funding sources.

Narayan et al., (2014) examined the influence of macroeconomic determinants on Indian bank stock 
performance through a Panel data model. They found that interest rate increases negatively impacted bank share prices. D'Apolito \& Pacelli, (2017) studied the impact of macroeconomic factors on the stock prices of European banks. It was found that Inflation rates and public borrowing influenced bank stock prices negatively. Menaje, (2012) studied the impact of macro factors such as the inflation rate, and 3-month T-bill yields on share prices of 10 listed banks on the Philippine stock exchange. It was found that 3-month Treasury bill rates negatively impacted share prices while inflation rate did not influence bank share prices.

The goods and market theory (Dornbusch \& Fischer, 1980) suggests that the effect of exchange rates on stock prices would depend on whether the economy is export or import dependent. For an export dependent economy, an appreciating currency would make its exports less competitive and thereby make companies less profitable. An import based economy on the other hand would benefit from a strong local currency as raw material costs and other production costs would reduce. Thus an inverse relationship between exchange rates and stock prices is likely in an export based economy while the reverse is true in an import driven economy. However a depreciating local currency would make foreign assets more attractive relative to local assets resulting in sell offs in domestic share prices suggesting a direct relationship between exchange rates and stock prices driven by capital and money flows as suggested in the portfolio balance approach (Tobin, 1969).

Lucky, Akani \& Chukwuemeka, (2015) examined the impact of varied macro variables such as exchange rate, Real Gross Domestic Product etc. on stock prices of Commercial banks in Nigeria and found a positive and significant relationship between the variables and stock prices. Narayan et al., (2014) found economic activity and currency depreciation resulted in rises in share prices of Indian bank stocks.

Ibrahim, (2000) looked at the influence of exchange rates on the Malaysian Stock Index. They found virtually no co-integration between the Malaysian stock index benchmark and exchange rates. However, when money supply and reserves were additionally included as variables in multivariate models some co-integration was observed between stock index performance and movement in exchange rates. Uddin, (2009) examined the influence of macro-economic variables on the share price performance of leasing and insurance companies in Bangladesh, using a multiple regression framework. The study observed that there was no relationship between share returns and the macro-economic factors chosen.

\section{Research Focus and Methodology}

\subsection{Research Focus}

The bank stock price has major implications for fund raising. It is a key component of important performance and valuation measures such as shareholder value creation over time, value creation measures such as market value added and key financial ratios such as the P/E ratio. While there are several studies on global bank profitability, determinants of bank stock prices in India, is still a rapidly evolving research area, and fewer studies are available in the Indian context. This study seeks to examine the influence of some of the above discussed micro and macro variables on the stock prices of private sector banks in India.

\subsection{Objectives of the Study}

The objectives of the study center on understanding the important drivers of stock prices of listed private sector banks in India. Specific objectives include:

1) Determining the influence of income measures and profitability on stock prices

2) Assessing the effect of lending activity and productivity on stock prices

3) Examining the influence of capital adequacy, asset quality, and liquidity measures on stock prices

4) Analyzing the impact of macro-economic indicators on stock prices

\subsection{Research Methodology}

This study used econometric principles to evaluate relationships between bank size and a select group of internal and external determinants. Historical data was used to study the relationship between key determinants and bank stock market capitalization. The sample consists of all listed Private sector banks in India with a listing history of at least 12 years, studied over twelve years between March 2008 and March 2019. The following variables have been considered for the study (Table 1): 
$\alpha_{i}$ denotes the intercept and $u_{i t}$ indicates the error term

A random-effects model is applicable when differences in groups influence the dependent variable. The randomeffects model is given by:

$$
\mathrm{y}_{\mathrm{it}}=\beta_{1} \mathrm{x}_{\mathrm{it}}+\alpha+\mathrm{u}_{\mathrm{it}}+\varepsilon_{\mathrm{it}}
$$

Here there are two error terms:

$\mathrm{u}_{\mathrm{it}}$ is the error term between groups and $\varepsilon_{i t}$ is the error term within groups

\section{Results}

This study looked at the influence of some key determinants on stock market capitalization of all listed private sector banks in India over the 12 years between 2008 and 2019 (Table 2).

\section{TABLE 2: LISTED PRIVATE SECTOR BANKS IN INDIA}

\begin{tabular}{|l|l|l|l|l|}
\hline Bank & $\begin{array}{l}\text { Market } \\
\text { Capitalization }\end{array}$ & Net Profit & Interest Income & Total Assets \\
\hline HDFC Bank (6) & $662,288.24$ & $26,257.32$ & $58,626.40$ & $1,530,511.26$ \\
\hline ICICI Bank (7) & $287,627.50$ & $7,930.81$ & $41,531.25$ & $1,098,365.15$ \\
\hline Kotak Mahindra Bank (12) & $272,523.03$ & $5,947.18$ & $13,429.95$ & $360,251.68$ \\
\hline Axis Bank (1) & $150,911.84$ & $1,627.22$ & $37,428.95$ & $915,164.82$ \\
\hline Indusind Bank (8) & $47,418.18$ & $4,417.91$ & $16,724.09$ & $307,057.55$ \\
\hline Yes Bank (15) & $32,370.94$ & $-16,418.03$ & $19,261.37$ & $257,826.92$ \\
\hline Federal Bank (5) & $11,220.05$ & $1,542.78$ & $8,561.85$ & $180,638.05$ \\
\hline City Union Bank (2) & $11,046.48$ & 476.32 & $2,493.41$ & $49,733.53$ \\
\hline DCB Bank (3) & $2,505.46$ & 337.94 & $2,271.72$ & $38,505.14$ \\
\hline Karur Vysya Bank (11) & $2,501.87$ & 235.02 & $3,642.04$ & $68,278.17$ \\
\hline Karnataka Bank (10) & $1,356.95$ & 431.78 & $4,444.41$ & $83,313.49$ \\
\hline South India Bank (14) & $1,192.61$ & 104.59 & $5,446.30$ & $97,032.90$ \\
\hline Jammu and Kashmir Bank (9) & $1,053.77$ & $-1,139.41$ & $4,739.62$ & $108,872.10$ \\
\hline Lakshmi Vilas Bank (13) & 584.20 & -836.04 & $1,778.96$ & $24,421.52$ \\
\hline Dhanlaxmi Bank (4) & 309.94 & 65.78 & 614.41 & $12,265.09$ \\
\hline
\end{tabular}

Source: Moneyontrol.com, As on: 21.10.2020, Annual Values in 10M Rupees.

Panel plots were obtained for all variables. The figure below shows panel plots for the dependent variable (Figure 1). This was used to determine the specifications for the Augmented Dickey-Fuller test.

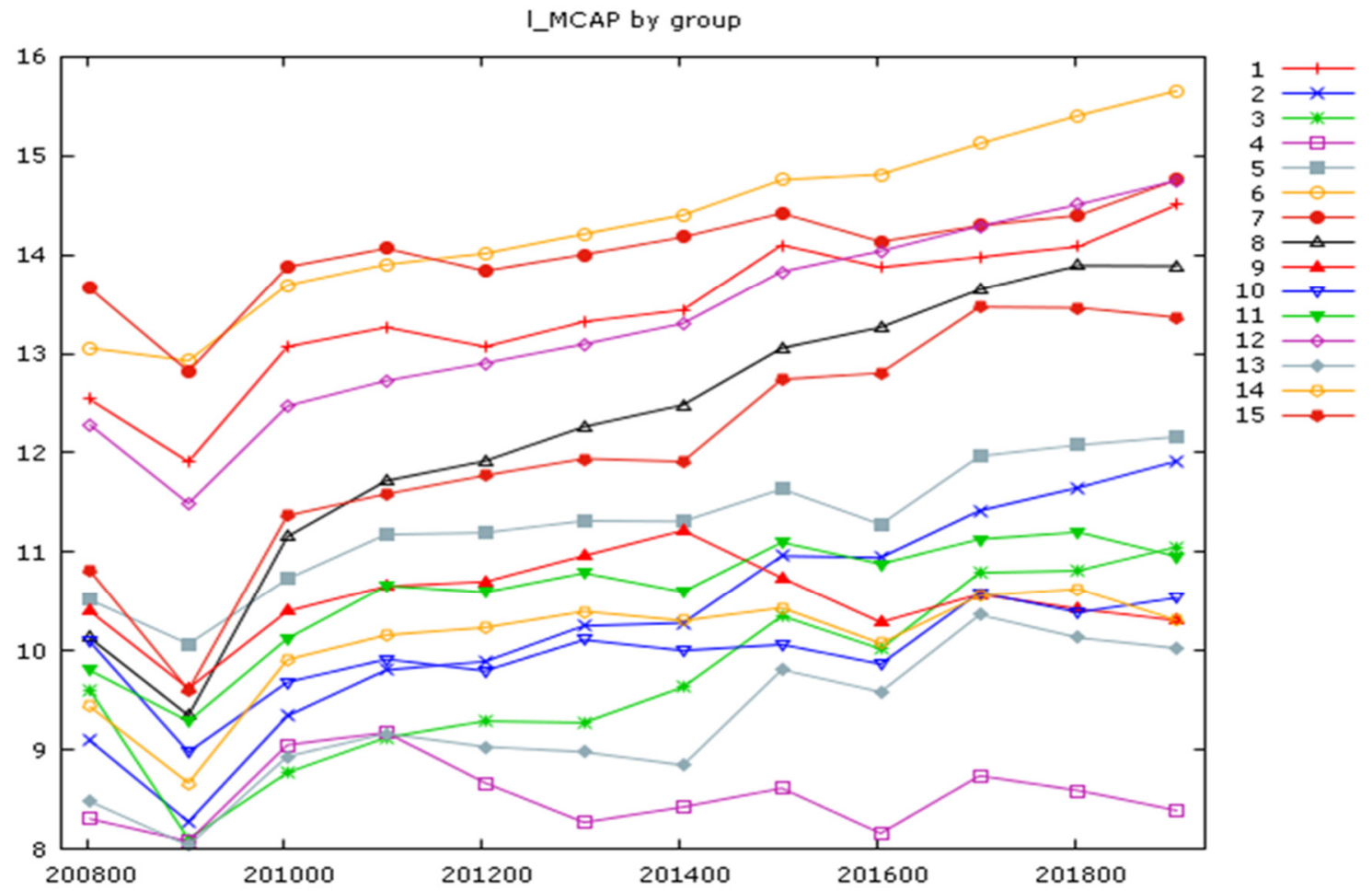

Figure 1: Panel Plots of the Dependent Variable

The Augmented Dickey-Fuller test was used to detect stationarity in the data. Variables that were not 
stationary were transformed by taking their respective natural logarithms (Table 3).

TABLE 3: RESULTS OF THE AUGMENTED DICKEY FULLER TEST FOR STATIONARITY

\begin{tabular}{|c|c|c|c|c|c|c|c|}
\hline Variable & $\begin{array}{l}\text { Test Statistic } \\
\mathrm{Chi}^{2}\end{array}$ & $\begin{array}{l}P \\
\text { Value }\end{array}$ & Inference & Variable & $\begin{array}{l}\text { Test } \\
\text { Statistic } \\
\text { Chi }^{2}\end{array}$ & $\begin{array}{l}P \\
\text { Value }\end{array}$ & Inference \\
\hline $\begin{array}{l}\text { Stock Market } \\
\text { Capitalization }\end{array}$ & 20.1055 & 0.9138 & $\begin{array}{l}\text { Not } \\
\text { stationary }\end{array}$ & Real GDP Growth & 297.055 & 0.0000 & Stationary \\
\hline $\begin{array}{l}\text { Ln (Stock Market } \\
\text { Capitalization) }\end{array}$ & 87.1631 & 0.0000 & Stationary & GDP Deflator & 418.844 & 0.0000 & Stationary \\
\hline $\begin{array}{l}\text { Interest Income to } \\
\text { Total Funds Ratio }\end{array}$ & 561.994 & 0.0000 & Stationary & Ln (GDP Deflator) & 520.94 & 0.0000 & Stationary \\
\hline $\begin{array}{l}\text { Noninterest Income } \\
\text { to Total Funds } \\
\text { Ratio }\end{array}$ & 126.403 & 0.0000 & Stationary & $\begin{array}{l}\text { Changes in } \\
\text { USD/INR exchange } \\
\text { rate }\end{array}$ & 197.862 & 0.0000 & Stationary \\
\hline $\begin{array}{l}\text { Interest Expended } \\
\text { to Interest Earned } \\
\text { Ratio }\end{array}$ & 131.012 & 0.0000 & Stationary & $\begin{array}{l}\text { Changes in Repo } \\
\text { Rate }\end{array}$ & 17.3391 & 0.9683 & $\begin{array}{l}\text { Not } \\
\text { stationary }\end{array}$ \\
\hline $\begin{array}{l}\text { The Return on } \\
\text { Assets (ROA) }\end{array}$ & 205.917 & 0.0000 & Stationary & $\begin{array}{l}\text { R \& D Expenses as a } \\
\text { Percentage of GDP }\end{array}$ & 1.30102 & 1.0000 & $\begin{array}{l}\text { Not } \\
\text { stationary }\end{array}$ \\
\hline $\begin{array}{l}\text { Credit Deposit } \\
\text { Ratio }\end{array}$ & 120.603 & 0.0000 & Stationary & $\begin{array}{l}\text { Ln (R \& D Expenses } \\
\text { as a Percentage of } \\
\text { GDP) }\end{array}$ & 6.08764 & 1.0000 & $\begin{array}{l}\text { Not } \\
\text { stationary }\end{array}$ \\
\hline $\begin{array}{l}\text { Business per } \\
\text { Employee }\end{array}$ & 42.5417 & 0.0643 & $\begin{array}{l}\text { Not } \\
\text { stationary }\end{array}$ & $\begin{array}{l}\text { Current Account } \\
\text { Balance as a } \\
\text { Percentage of GDP }\end{array}$ & 13.8131 & 0.9949 & $\begin{array}{l}\text { Not } \\
\text { stationary }\end{array}$ \\
\hline $\begin{array}{l}\text { Ln (Business per } \\
\text { Employee) }\end{array}$ & 268.6 & 0.0000 & Stationary & $\begin{array}{l}\text { External Debt as a } \\
\text { Percentage of GDP }\end{array}$ & 40.8773 & 0.0890 & $\begin{array}{l}\text { Not } \\
\text { stationary }\end{array}$ \\
\hline $\begin{array}{l}\text { Capital Adequacy } \\
\text { Ratio }\end{array}$ & 491.548 & 0.0000 & Stationary & $\begin{array}{l}\text { Ln (External Debt as } \\
\text { a Percentage of } \\
\text { GDP) }\end{array}$ & 30.5025 & 0.4401 & $\begin{array}{l}\text { Not } \\
\text { stationary }\end{array}$ \\
\hline $\begin{array}{l}\text { Net Non- } \\
\text { Performing Assets }\end{array}$ & 50.9083 & 0.0100 & Stationary & $\begin{array}{l}\text { Trade Balance as a } \\
\text { Percentage of GDP }\end{array}$ & 32.9916 & 0.3229 & $\begin{array}{l}\text { Not } \\
\text { stationary }\end{array}$ \\
\hline $\begin{array}{l}\text { Ln (Net Non- } \\
\text { Performing Assets) }\end{array}$ & 103.212 & 0.0000 & Stationary & $\begin{array}{l}\text { Government } \\
\text { Lending / Borrowing } \\
\text { as a Percentage of } \\
\text { GDP }\end{array}$ & 191.649 & 0.0000 & Stationary \\
\hline $\begin{array}{l}\text { Investment Deposit } \\
\text { Ratio }\end{array}$ & 48.5447 & 0.0175 & Stationary & $\begin{array}{l}\text { Public Debt as a } \\
\text { Percentage of GDP }\end{array}$ & 8.08121 & 1.0000 & $\begin{array}{l}\text { Not } \\
\text { stationary }\end{array}$ \\
\hline Cash Deposit Ratio & 354.565 & 0.0000 & Stationary & $\begin{array}{l}\text { Ln (Public Debt as a } \\
\text { Percentage of GDP) }\end{array}$ & 8.95551 & 0.9999 & $\begin{array}{l}\text { Not } \\
\text { stationary }\end{array}$ \\
\hline GDP & 0.000956329 & 1.0000 & $\begin{array}{l}\text { Not } \\
\text { stationary }\end{array}$ & $\begin{array}{l}\text { Consumer } \\
\text { Expenditure as a } \\
\text { Percentage of GDP }\end{array}$ & 2.20908 & 1.0000 & $\begin{array}{l}\text { Not } \\
\text { stationary }\end{array}$ \\
\hline Ln (GDP) & 46.3935 & 0.0285 & Stationary & $\begin{array}{l}\text { Ln (Consumer } \\
\text { Expenditure as a } \\
\text { Percentage of GDP) }\end{array}$ & 2.30967 & 1.0000 & $\begin{array}{l}\text { Not } \\
\text { stationary }\end{array}$ \\
\hline
\end{tabular}

The test for poolability showed that a pooled OLS model is not relevant and a fixed or random-effects model is more appropriate (Table 4).

TABLE 4: TEST FOR POOLABILITY

\begin{tabular}{|l|l|l|l|}
\hline Test & Null Hypothesis & Test Statistic Welch $F$ & P value \\
\hline Test for poolability & $\begin{array}{l}\text { The groups have a common } \\
\text { intercept }\end{array}$ & 109.775 & 0.0000 \\
\hline
\end{tabular}

The Hausman test suggested that a fixed-effects model was preferred over a random-effects model (Table 5).

TABLE 5: HAUSMAN TEST

\begin{tabular}{|l|l|l|l|}
\hline Test & Null Hypothesis & Test Statistic Chi $^{2}$ & P value \\
\hline Hausman test & $\begin{array}{l}\text { A random effects model is } \\
\text { appropriate }\end{array}$ & 272.528 & 0.0000 \\
\hline
\end{tabular}

A fixed-effect panel regression was performed between the dependent variable Ln (Stock Market 
Capitalization) and all the independent variables. The influencing independent variables as indicated by the $\mathrm{P}$ Values were the Cash Deposit Ratio, ROA, Real GDP Growth, Ln (GDP Deflator), and Changes in the USD/INR exchange rate ((Tables 6,7$)$. The LSDV R2 suggested a strong relationship between the variables. AIC values confirmed the goodness of fit. The Durbin Watson coefficient suggested the presence of some autocorrelation (Tables 6, 7).

TABLE 6: RESULTS OF FIXED EFFECT PANEL REGRESSION, LN (STOCK MARKET CAPITALIZATION) = FUNCTION (ALL INDEPENDENT VARIABLES)

\begin{tabular}{|c|c|c|c|c|}
\hline $\begin{array}{l}\text { Dependent } \\
\text { Variable }\end{array}$ & Independent Variable & Coefficient & $\begin{array}{l}P \\
\text { Value }\end{array}$ & $\begin{array}{l}\text { LSDV R } R^{2} / A I C / \\
\text { Durbin Watson }\end{array}$ \\
\hline \multirow{16}{*}{$\begin{array}{lcc}\text { Ln (Stock } & \text { Market } \\
\text { Capitalization) } & \\
\end{array}$} & Constant & -15.1461 & 0.2272 & $0.97 / 176.35 / 0.54$ \\
\hline & Credit Deposit Ratio & 0.0250382 & 0.0849 & \\
\hline & Investment Deposit Ratio & -0.0116540 & 0.5309 & \\
\hline & Cash Deposit Ratio & 0.0819373 & 0.0445 & \\
\hline & Capital Adequacy Ratio & 0.0375185 & 0.2058 & \\
\hline & $\begin{array}{l}\text { Interest Expended to Interest Earned } \\
\text { Ratio }\end{array}$ & 0.00962392 & 0.1280 & \\
\hline & $\begin{array}{l}\text { Interest Income to Total Funds } \\
\text { Ratio }\end{array}$ & -0.0236061 & 0.7870 & \\
\hline & $\begin{array}{l}\text { Noninterest Income to Total Funds } \\
\text { Ratio }\end{array}$ & 0.309801 & 0.1074 & \\
\hline & Ln (Business per Employee) & 0.0940960 & 0.0621 & \\
\hline & ROA & 0.200642 & 0.1247 & \\
\hline & Ln (Net Non-Performing Assets) & -0.113540 & 0.3462 & \\
\hline & Ln (GDP) & 0.129687 & 0.9189 & \\
\hline & Real GDP Growth & -0.0527263 & 0.0167 & \\
\hline & Ln (GDP Deflator) & 4.27014 & 0.1359 & \\
\hline & $\begin{array}{l}\text { Government Lending / Borrowing } \\
\text { as a Percentage of GDP }\end{array}$ & -0.0576029 & 0.4564 & \\
\hline & Changes in USD/INR exchange rate & -2.33648 & 0.0000 & \\
\hline
\end{tabular}

TABLE 7: RESULTS OF FIXED EFFECT PANEL REGRESSION, LN (STOCK MARKET CAPITALIZATION) $=$ FUNCTION (INFLUENCING VARIABLES)

\begin{tabular}{|l|l|l|l|l|}
\hline Dependent Variable & Independent Variable & Coefficient & P Value & $\begin{array}{l}\text { LSDV R / AIC / } \\
\text { Durbin Watson }\end{array}$ \\
\hline $\begin{array}{l}\text { Ln (Stock Market } \\
\text { Capitalization) }\end{array}$ & Constant & -10.6275 & 0.0000 & $\begin{array}{l}0.96 / 193.77 / \\
0.48\end{array}$ \\
\hline & Cash Deposit Ratio & 0.117971 & 0.0010 & \\
\hline & ROA & 0.317106 & 0.0000 & \\
\hline & Real GDP Growth & -0.0417343 & 0.0259 & \\
\hline & Ln (GDP Deflator) & 4.43099 & 0.0000 & \\
& $\begin{array}{l}\text { Changes in USD/INR } \\
\text { exchange rate }\end{array}$ & -2.37210 & 0.0000 & \\
\hline
\end{tabular}

\section{Model Fit:}

Based on the panel regression results (Table 6) the following model is proposed: $\operatorname{Ln}(\mathrm{MCAP})=-10.6275+0.117971 \mathrm{CaDR}+0.317106 \mathrm{ROA}+4.43099 \mathrm{GDPD}-0.0417343 \mathrm{RGDPG}$

$$
-2.37210 \operatorname{Ln}\left((\mathrm{USDINR}) \mathrm{t} /(\mathrm{USDINR})_{\mathrm{t}-1}\right)+
$$

\section{Discussion and Analysis}

This research study examined the factors influencing stock market capitalization of India's listed private sector banks. The stock price being the bank's ticket to fund raising, is a key component of major performance, and valuation measures like shareholder value creation, market value added, and key financial ratios. All listed private sector banks with a listing history of at least 5 years were studied over the 12 years between 2008 and 2019 (Table 2).

The natural logarithm of the stock market capitalization of the sample banks served as the dependent variable. The key determinants studied included a wide range of micro and macro variables. Micro factors included measures of income, profitability, lending, productivity, capital adequacy, asset quality and liquidity. The macro 
factors chosen were measures of growth, inflation, government borrowing and expenditure, consumer expenditure, interest and exchange rates (Table 1). Panel regression analysis was used to analyze the influence of these determinants on stock market capitalization.

Profitability as indicated by the ROA had a positive impact on stock market capitalization (Table 7). Rjoub et al., (2017) have similarly found that profitability as indicated by key earnings measures, had a positive impact on stock prices of Turkish banks.

Asset quality did not influence stock market capitalization (Table 7). While asset quality issues have been impacting the private sector banking landscape for well over a decade, it is not a major driver of bank share prices. D'Apolito and Pacelli, (2017) however found asset quality to be a key determinant of the share prices of European banks.

A Liquidity measure the cash deposit ratio influenced bank size positively (Table 7) suggesting the banks that manage their liquidity better can deliver better returns to their shareholders. D'Apolito and Pacelli, (2017) similarly found liquidity to be a major influencer of the share prices of European banks.

Real GDP growth impacted bank share prices negatively in this study (Table 7). Private bank stock prices in India have increased significantly despite very anemic economic growth. Ali et al., (2018) however found that share prices of banks in Pakistan, studied between 2005 and 2013, rose during booms in economic activity.

Inflation also had a positive impact on bank share prices in this study (Table 7). Presence of inflation results in a steeper yield curve, which is good for bank margins, which in turn positively impacts bank stock prices as observed in the study. This gives credence to the Fisher effect (Fisher, 1930), suggesting that bank stocks could provide good inflation adjusted returns. Eita, (2012) however observed that inflation impacted share prices in Namibia negatively.

Increases in the USD/INR exchange rate, implying a depreciation in the Rupee, impacted bank share prices negatively (Table 7). Significant weakness in the Rupee often occurs during major crisis periods that resulted in depressed bank stock prices. Ali et al., 2018 similarly found periods of currency depreciation produced lower bank stock prices in Pakistan. Narayanan et al., 2014 however observed currency depreciation to be positive for bank stock prices in India.

Thus Liquidity, profitability, growth, inflation and exchange rate indicators proved to be key influencers of the stock prices of private sector banks in India (Figure 2). Recently the RBI has dramatically increased liquidity in the system with a series of rate cuts, which is a positive for bank stock prices. Profit margins however remain under pressure in a deflationary environment which has seen a steady depreciation of the local currency the Rupee, thus rebounding bank stock prices may hit head winds in the not too distant future.

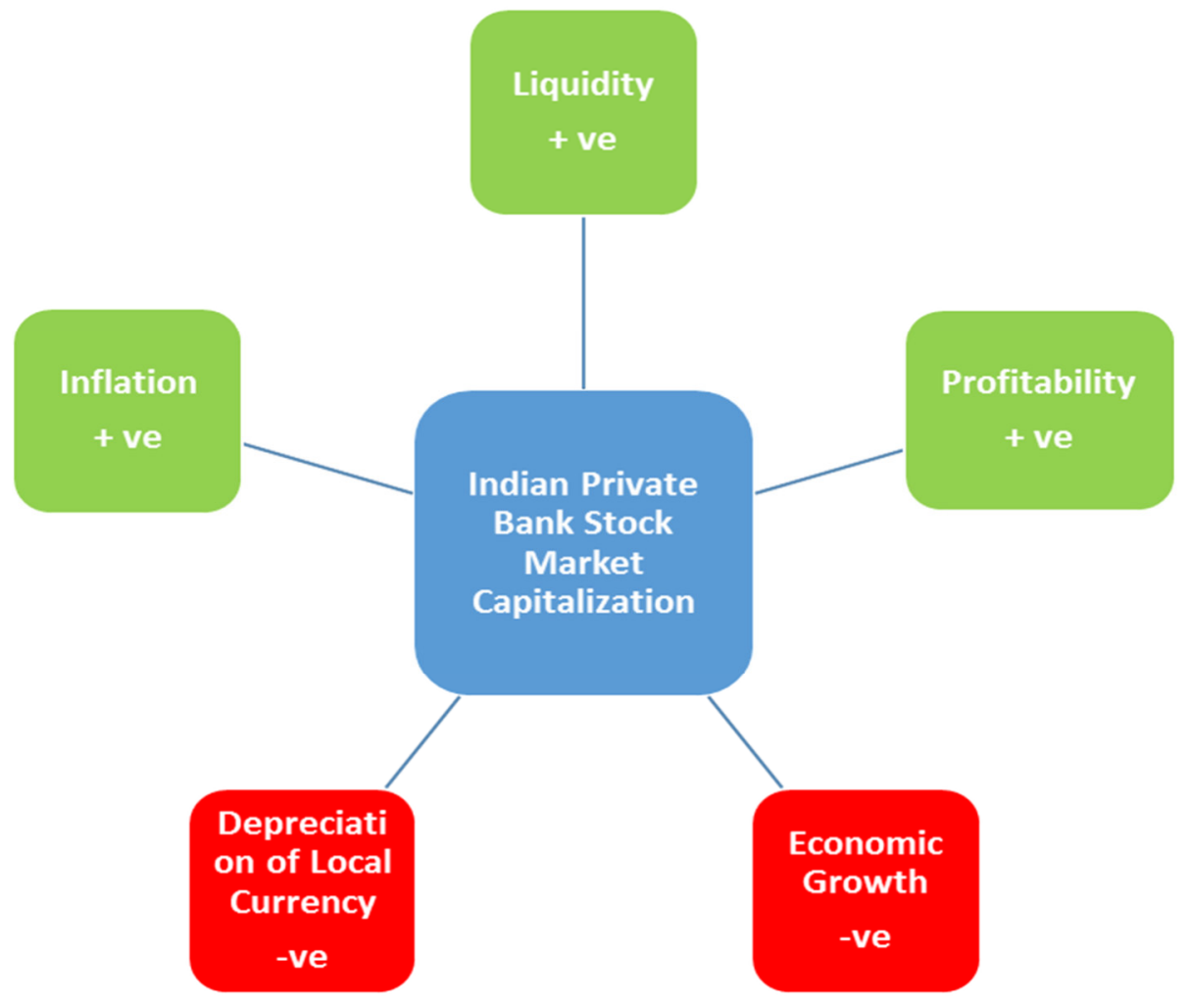

Figure 2: Construct developed based on the study 
The study has implications for key stakeholders of banks. Bank managers can focus on measures to improve profitability. Bank managers can also ensure their banks have ample liquidity, and have adequately hedge exchange rate risk exposure to deliver superior returns to their shareholders.

Investors can identify adequately liquid, profitable banks that have diversified income streams. Investors can also focus on well-hedged banks good margins as these banks tend to deliver more shareholder value over time when compared to their counterparts, as there is evidence for the fisher effect in this study (Fisher, 1930).

The Regulators can provide more functional autonomy to liquid, profitable banks that have adequately protected themselves against external shocks and consistently outperform their peers.

\section{Conclusion}

This study examined the influence of some key micro and macro determinants on the stock prices of listed private sector banks in India. The dependent variable in the study was the natural logarithm of stock market capitalization. The micro determinants selected were measures of income, profitability, lending, productivity, capital adequacy, asset quality and liquidity. The macro determinants studied were measures of growth, inflation, government borrowing and expenditure, consumer expenditure, interest and exchange rates.

Measures of profitability, liquidity, growth, inflation, and exchange rates were found to be influential determinants of private sector bank stock prices in India. Thus bank managers must focus on improving liquidity and profitability of their respective banks. They must adequately insulate their banks from exchange rate risks in a potentially deflationary environment.

Investors can focus on these parameters to identify shareholder-friendly banks that provide good hedges against inflation. Regulators can monitor these parameters as they seek to help banks overcome the ever-present challenges that constantly emerge in today's ever-changing Indian banking landscape.

The scope of the study can be extended to include Public Sector Banks and Foreign Banks operating in India to make it more comprehensive and to serve as an input for development of relevant policy framework by Regulators.

\section{References}

Ali, S., Bashir, T., Ahmed, T., Ishaq, A., \& Shahzad, S. J. H. (2018). The Determinants of Bank Stock Prices: A Panel Approach. South Asian Journal of Management Sciences, 12(2), 116-129.

Ali, M.B. \& Chowdhury, T.A. (2010).Effect of dividend on stock price in emerging stock market: A study on the listed private commercial banks in DSE. International Journal of Economics and Finance, 2(4), 52-64.

Al-Shubiri, F N (2010). Analysis the determinants of Market price movements: An Empirical study of Jordanian Commercial Banks. International Journal of Business and Management. 5(10); October 2010; 137-147.

Almumani, M. A. (2014). Determinants of Equity share prices of the Listed banks in Amman Stock Exchange: Quantitative Approach. International Journal of Business and Social Science, Vol. 5 No. 1:January 2014, 91104.

Beccalli, E., Casu, B., \& Girardone, C. (2006). Efficiency and Stock Performance in European Banking. Journal of Business Finance \& Accounting, 33(1-2), 245-262.

D’Apolito, E., \& Pacelli, V. (2017). What Influences Bank Stock Prices in Times of Crisis? An International Survey. International Journal of Economics and Finance, 9(6), 1

Dickey, D.A., and Fuller, W.A. (1979) Distribution of the estimators for autoregressive time series with a unit root. Journal of the American Statistical Association, 74, 427-431.

Dietrich, A., \& Wanzenried, G. (2011). Determinants of bank profitability before and during the crisis: Evidence from Switzerland. Journal of International Financial Markets, Institutions and Money, 21(3), 307-327.

Dornbusch, R., and S. Fischer. (1980). Exchange Rate and the Current Account. American Economic Review 70 (5): 960-971.

Eita, J. H. (2012). Modelling macroeconomic determinants of stock market prices: Evidence from Namibia. Journal of Applied Business Research, 28(5), 871-884.

English, W. B., Van den Heuvel, S. J., \& Zakrajšek, E. (2018). Interest rate risk and bank equity valuations. Journal of Monetary Economics, 98, 80-97.

Fama, E. F. (1981). Stock returns, real activity, inflation, and money. American Economic Review, 71(4), 545565.

Fisher, I. (1930). The theory of interest (pp. 21-27). New York: Macmillan.

Ghauri, S. M. K. (2014). Determinants of changes in share prices in banking sector of Pakistan. Journal of Economic and Administrative Sciences, 30(2), 121-130.

Ibrahim, M. H. (2000). Cointegration and granger causality tests of stock price and exchange rate interactions in Malaysia. Asian Economics Bulletin, 17(1), 36-47.

Kazi, M. H. (2009). An application of co-integration technique for detecting influential risk factors of the Australian stock market. International Research Journal of Finance and Economics, 1(25), 78-89. 
Lucky, A.L., Akani, H.W. \& Chukwuemeka, A. (2015). Prudential determinants of stock prices of Commercial Banks in Nigeria: an Application of Fundamentalists and Macroeconomic view. 1980-2014. ILARD International Journal of Banking and Finance Research, ISSN 2695-186X Vol. 1 No. 8 2015, 84-109.

Menaje, P. M. (2012). Impact of Selected Financial Variables on Share Price of Publicly Listed Firms in the Philippines. American International Journal of Contemporary Research, 2(9), 98-104.

Naveed, M.Y. \& Ramzan, M. (2013). A view about the determinants of change in share prices: A case from Karachi stock exchange (Banking sector). Interdisciplinary Journal of Contemporary Research in Business, April 2013, Vol.4, No. 12, 41-57.

Narayan, P. K., Narayan, S., \& Singh, H. (2014). The determinants of stock prices: New evidence from the Indian Banking Sector. Emerging Markets Finance and Trade, 50(2), 5-15.

Pasiouras, F., Liadaki, A., \& Zopounidis, C. (2008). Bank efficiency and share performance: Evidence from Greece. Applied Financial Economics, 18(14), 1121-1130.

Rjoub, H., Civcir, I., \& Resatoglu, N. G. (2017). Micro and macroeconomic determinants of stock prices: The case of Turkish banking sector. Romanian Journal of Economic Forecasting, 20(1), 150-166.

Seetharaman, A., \& Raj, J. R. (2011). An Empirical Study on the Impact of Earnings per Share on Stock Prices of a Listed Bank in Malaysia. The International Journal of Applied Economics and Finance, 5(2), 114-126.

Srinivasan, P. (2012). Determinants of Equity share prices in India: A Panel Data Approach. The Romanian Economic Journal. Year XV no. 46, 205-228, December.

Tobin, J. (1969). A general equilibrium approach to monetary theory. Journal of Money, Credit and Banking, $1(1): 15-29$.

Uddin, M. B. (2009). Determinants of market price of stock: A study on bank leasing and insurance companies of Bangladesh. Journal of Modern Accounting and Auditing, 5(7), 1-7.

Rajveer S Rawlin received his PhD from Bharathiar University, Tamil Nadu, India and his MBA in Finance from the Cardiff Metropolitan University, Wales, UK. He teaches in the Department of Finance \& BFSI at M S Ramaiah Institute of Management. His research interests include areas of Capital Markets, Investment Analysis and Portfolio Management and has more than 25 years of experience in the above covering the US and Indian Markets. He is the author of the popular blog: Ahead of the curve. He reviews for Emerald and Sage.

Savitha Rani Ramachandran received her PhD from Dr. MGR Educational \& Research Institute (Deemed University), Chennai and her MBA in Finance from Bharthidasan Institute of Management, Tamil Nadu. She is a Fellow of the Institute of Cost Accountants of India, Kolkata. Her research interests include Capital Markets, Investment Analysis and Portfolio Management and Consumer Buying Behaviour. She has more than 20 years of academic experience and 8 years of corporate experience.

Keerthana K R is a Graduate Student of M S Ramaiah Institute of Management, Bengaluru. 